\title{
Studies on the lipid constituents of grape seeds recovered from pomace resulting from white grape processing
}

\author{
By S.M. El-Shami, M.H. El-Mallah and SS. Mohamed \\ Fats and Oils Dept., National Research Centre, Dokki, Cairo, Egypt
}

\section{RESUMEN}

Estudios sobre los constituyentes lipídicos de semillas de uva recuperadas de la pulpa resultante del procesado de uva blanca

Se han realizado estudios sobre los constituyentes lipidicos de semillas de uva producidas como subproducto del procesado de uva blanca. La cromatografía gas-líquido se usó para determinar la composición de ésteres metilicos de ácidos grasos y silil derivados esteroles del aceite. Se observó que el aceite contenia cantidades apreciables de ácidos grasos insaturados, principalmente ácidos oleico y linoleico, no siendo sin embargo detectado el ácido linolénico. Se encontraron en cantidades razonables ácidos grasos saturados, principalmente, palmítico y esteárico. Como componentes minoritarios se detectaron los ácidos miristico palmitoleico, eicosanoico y eicosadienoico. El isofucosterol apareció junto a otros esteroles, principalmente, campesterol, estigmasterol y beta-sitosterol. El análisis por HPLC del aceite para la determinación de tocoferoles, mostró la presencia de alfa- y gamma-tocotrienoles, y alfa- $y$ gamma- tocoferoles en cantidades de 53'2, 28'6, 16'4 y $1^{\prime} 8$ respectivamente. El contenido en tocoferoles totales del aceite fue de $470 \mathrm{ppm}$. En la harina desgrasada de semillas de uva se vio un contenido del $24,6 \%$ en proteína, con amplias proporciones de todos los aminoácidos esenciales, determinados mediante analizador de aminoácidos.

PALABRAS-CLAVE: Composición lipldica - Proceso tecnológico Semilla de uva - Subproducto.

\section{SUMMARY}

Studies on the lipid constituents of grape seeds recovered from pomace resulting from white grape processing

Studies on the lipid constituents of grape seeds, produced as by-product from white grape processing, were carried out. Gas liquid chromatography was used to determine the composition of fatty acid methyl esters and sterol silyl derivatives of the oil. The oil was found to contain appreciable amount of unsaturated fatty acids, namely, oleic and linoleic acids, however, linolenic acid was not detected. Saturated fatty acids, namely, palmitic and stearic were found to be present in reasonable amounts. Myristic, palmitoleic, eicosanoic and eicosadienoic acids were detected as minor components. Isofucosterol was found among the other sterol constituents namely, campesterol, stigmasterol and beta-sitosterol. HPLC analysis of the oil for determination of tocopherols, showed the presence of alpha-and gamma-tocotrienols, and alpha-and gamma-tocopherols to the extent of $53.2,28.6,16,4$ and $1,8 \%$ respectively. The total tocopherols content of the oil was $470 \mathrm{ppm}$. The defatted meal of grape seeds was found to contain $24,6 \%$ protein which contained large proportions of all the essential amino acids as determined by amino acid analyzer.

KEY-WORDS: By-product - Grape seed - Lipid composition - Technological process.

\section{INTRODUCTION}

Different kinds of grapes are locally cultivated in Egypt and large amounts are consumed as fresh fruits, howe- ver, some grape varieties are mainly cultivated for producing wine, raisins, juices and other unfermented beverages. Grape seeds are considered to be a potential source of oil which constitutes about $15 \%$ of the weight of the seeds (1).

Several publications, concerning foreign grape seed varieties, dealt with the determination of lipid and protein constituents of the seeds (2-22). Only few publications on the Egyptian grape seed varieties (namely, Fayoumi, Bezzelanza and Moskat) were concerned with fatty acid composition and determination of some triglyceride components with the help of argentation and partition thin layer chromatography (23) (24). Hassan et al. (25) studied only the fatty acid composition of Egyptian white and red grape seed varieties with ultraviolet spectroscopy and chromatographic methods of analysis.

It was the objective of the present work to carry out detailed studies on grape seeds that are produced in tonnages as by-product from white grape processing. The studies were chiefly concerned with elucidation of fatty acid, sterol and tocopherol composition using gas liquid and high performance liquid chromatography. Additional studies on the response of the crude oil to refining and bleaching processes, were also carried out. With the aim of throwing light on the possibility of using the defatted seeds as feed components, protein and the amino acid constituents were quantitatively determined.

\section{EXPERIMENTAL}

The pomace, produced as by-product of white grape processing, was obtained from the Egyptian Vineyards and Distilleries Company (Ginaclis), season 1990. The fresh pomace (containing about $50 \%$ grape seeds) was placed on trays and subsequently dried in air and oven. The grape seeds were sieved out from dry pomace and solvent extracted by commercial $n$-hexane. The solvent was removed in a rotary evaporator and the oil was kept in stoppered bottles in the refrigerator.

Physical and chemical characteristics of the oil were determined using the official methods of analysis (26).

Nitrogen content of the defatted meal was determined 
by applying a semimicro Kjeldahl procedure and the protein content was calculated as $N \times 6,25$ (27). Quantitative determination of the individual amino acids, in protein hydrolyzate, was carried out with the help of automatic amino acid analyzer (28) (29).

Crude oil was alkali refined with $20^{\circ} \mathrm{Be} \mathrm{NaOH}(30)$ and the refined oil was then bleached with $3 \%$ Tonsil $N$ clay of the weight of the refined oil. The oil and clay mixture was heated at $110^{\circ} \mathrm{C}$ for 10 minutes under $\mathrm{N}_{2}$ atmosphere while stirring. Colours of the crude, refined and refined-bleached oils were evaluated spectrophotometrically (Shimadzu Spectrophotometer UV-240) at wave lengths ranging from 300 to $700 \mathrm{~nm}$. The colour index for the three oils was also calculated following the recommendation of Pons et al. (31).

Tocopherol constituents were measured directly in the oil using Toyo Soda CCPM high pressure liquid chromatograph (HPLC) instrument coupled to Hitachi-650-10 $S$ fluorescence detector with an excitation and emmission wave lengths of 290 and $325 \mathrm{~nm}$ respectively. A column $(150 \times 4,6 \mathrm{~mm})$ packed with silica gel YMC-A-012 SIL was eluted with the solvent hexane: isopropyl alcohol $(100: 0,5 \mathrm{v} / \mathrm{v})$ at flow rate $1-2 \mathrm{ml} / \mathrm{min}$. Sample size of 20 microliter of $1-1,5 \mathrm{ml}$ oil dissolved in $100 \mathrm{ml}$ hexane was injected (32).

Sterol constituents were determined by gas liquid chromatographic analysis (GLC) as TMS derivatives. Hewlett-Packard HP 5890 A gas chromatograph was used under the following operating conditions: column, 0,53 $\mathrm{mm} \times 5 \mathrm{~m}$ coated with DB-1 phase in a film thickness of 1,0 micron; column temperature, $200-280^{\circ} \mathrm{C}$ with a rate of $4^{\circ} \mathrm{C} / \mathrm{min}$; injection and detector temperature, $290^{\circ} \mathrm{C}$, and carrier gas was helium at flow rate of $8,0 \mathrm{ml} / \mathrm{min}$. Preparation of pure sterols mixture and their silyl derivatives, and gas chromatographic analysis were conducted according to Slover et al. (33) and El-Shami (34).

GLC analysis of fatty acids, of grape seed oil in comparison with those of cottonseed and soybean oils was carried out using the same instrument but under the following operating conditions: column, $30 \mathrm{~m} \times 0,32 \mathrm{~mm}$ filled with DB-23 in a film thickness of 0,25 micron; column temperature, $150-230^{\circ} \mathrm{C}, 3^{\circ} \mathrm{C} / \mathrm{min}$; injection temperature, $230^{\circ} \mathrm{C}$; detector, flame ionization; carrier gas, helium at $1-3 \mathrm{ml} / \mathrm{min}$ and split ratio of 1:100.

\section{RESULTS AND DISCUSSION}

Grape seeds contain reasonable amounts of oil and protein $(14,6 \%$ and $24,6 \%$ respectively) which are generally lower than the other conventional oil seeds (1). The iodine value of the oil is 128 (Table I) which indicates that this oil belongs to the class of semi-drying oils. It is also observed that the crude oil contains free acidity of $3,45 \%$ (as oleic acid) and peroxide value of 8,5 . It can be concluded that acidity and hydroperoxides may arise from some enzymatic reactions taking place during grinding of the seeds although crude oil was extracted from the seeds directly after grape pressing.
Table I

Grape Seed Oil Characteristics

\begin{tabular}{lc}
\hline Refractive Index & 1,4690 \\
lodine value & 128,0 \\
Saponification value & 212,0 \\
Unsaponifiable Matter \% & 3,1 \\
\cline { 2 - 2 } Free acidity (Oleic \%) 3,45\%, Peroxide value: & 8,5
\end{tabular}

To throw light on the autoxidation potential of the oil, it was advisable to determine quantitatively tocopherol constituents by HPLC which shows that the oil contains a considerable amount of tocopherols and tocotrienols amounting to $470 \mathrm{ppm}$ (mg tocopherol $/ \mathrm{kg}$ oil). Alpha- tocotrienol is the most predominant compound and constitutes $53,2 \%$ of the total tocopherols and tocotrienols (Table II). Gamma-tocotrienol, alpha-and gamma-tocopherols are found at the levels of $28,6,16,4$ and $1,8 \%$ respectively.

Table II

HPLC Analysis of Tocopherols Constituents

\begin{tabular}{lr}
\hline Total tocopherols & $470 \mathrm{ppm}$ \\
Alpha-Tocopherol & $16,4 \%$ \\
Gamma-Tocopherol & $1,8 \%$ \\
Alpha-Tocotrienol & $53,2 \%$ \\
Gamma-Tocotrienol & $28,6 \%$
\end{tabular}

Considering the fact that grape seed oil can be used mainly for edible and pharmaceutical purposes, refining as well as bleaching were carried out to obtain an oil of more acceptable and desirable colour to the customers and to get rid of the pigments that can play roles as prooxidants. The response of the oil to refining was followed by measuring the colour by both Lovibond and spectrophotometric methods. The colours of the crude, refined and refined-bleached oils are recorded in Table III. It can be noticed that the pigments respond quite well to bleaching and therefore the colour is more greatly reduced by the bleaching than by the refining process alone. The influence of both refining and bleaching processes on the removal of pigments was followed spectrophotometrically.

Table III

Studies on the Colour of Crude, Refined and Bleached Grape Seed Oil

\begin{tabular}{lccc}
\hline Colour (A) & Crude Oil & Refined oil & Bleached oil \\
\hline Yellow (y) & 12 & 12 & 0,1 \\
Red (R) & 1,1 & 0,7 & - \\
Blue (B) & 0,1 & - & - \\
Y $+10 R$ & 23,0 & 19,0 & 0,1 \\
R + B & 1,2 & 0,7 & - \\
Colour Index (B) & 486,8 & 273,8 & 16,08 \\
\hline
\end{tabular}

A: As Lovibond Units, B as Colour Index (Spectrophotometrically 400-550 $\mathrm{nm})$. 
The absorption curve of the crude oil shows clearly maxima at about 670 and $610 \mathrm{~nm}$ which are characteristic to chlorophylls and/or their derivatives. Other maxima at 535 and $560 \mathrm{~nm}$, contributed by flavonoids, also appear. In addition, the absorption curve also shows absorption at lower wave lengths of $415,435,455$ and $485 \mathrm{~nm}$ which are characteristic to carotenoid pigments. It can be noticed from the absorption spectra, that refining alone could not remove the chlorophylls and carotenoids completely, while refining followed by bleaching removed effectively all the absorption bands belonging to the different pigments. Therefore refining followed by bleaching removes effectively the pigments that enhance autoxidation reactions, thus avoiding any prooxidant activity in the oil (35) (36).

The fatty acid pattern of grape seed oil shows that it is rich in both oleic and linoleic acids, however, linolenic acid is not detected. Comparing the fatty acid patterns of grape seed, cottonseed and soybean oils (Table IV) it is found that the oil has a similar composition to cottonseed oil and therefore problems encountered with flavour instability, arising from linolenic acid, is avoided.

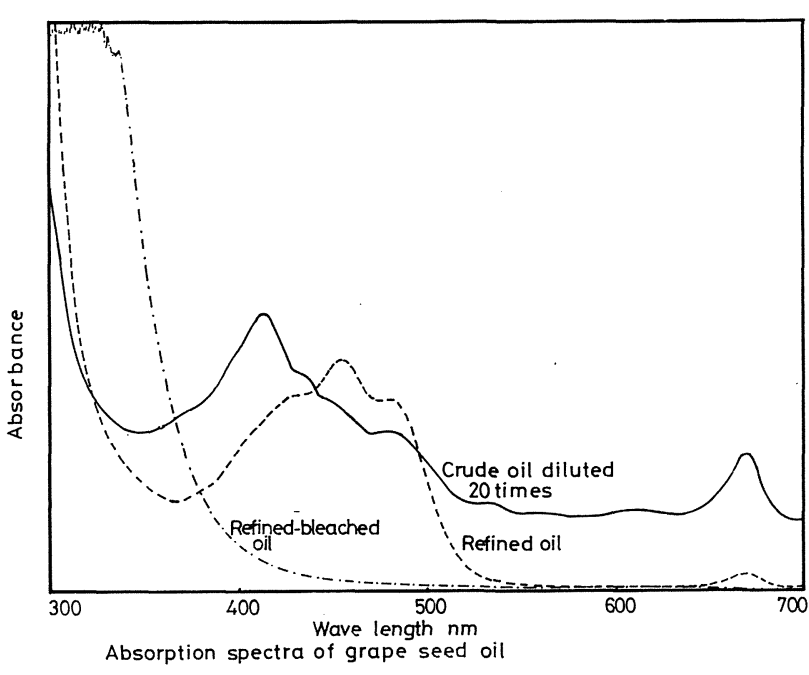

Figure 1

Absorption spectra of grape seed oil

Table IV

Fatty Acid Pattern of Grape Seed Oil in Comparison With Cottonseed and Soybean Oils

\begin{tabular}{lccccccccc}
\hline & $C_{14: 0}$ & $C_{16: 0}$ & $C_{16: 1}$ & $C_{18: 0}$ & $C_{18: 1}$ & $C_{18: 2}$ & $C_{18: 3}$ & $C_{20: 0}$ & $C_{20: 2}$ \\
\hline Grape seed oil & 0,4 & 12,8 & 0,2 & 7,9 & 28,9 & 49 & - & 0,2 & 0,6 \\
Cottonseed oil & 1,0 & 25,2 & 0,9 & 3,0 & 20,3 & 48,7 & - & 0,3 & - \\
Soybean oil & - & 12,6 & - & 6,5 & 30,1 & 44,4 & 6,4 & - & - \\
\hline
\end{tabular}

To complete the picture, it was of interest to determine the sterol constituents of the oil by GLC analysis. Pure sterols, isolated from the unsaponifiable matter, were analyzed by GLC as their TMS derivatives. The analysis shows four sterols i.e., campesterol, stigmasterol, beta-sitosterol and isofucosterol at the levels of $10,6,13,7$, 73,8 and $1,9 \%$, respectively (Table V).

Table V

GLC Analysis of Sterols Constituents

\begin{tabular}{lr}
\hline Campesterol & $10,6 \%$ \\
Stigmasterol & $13,7 \%$ \\
Beta-Sitosterol & $73,8 \%$ \\
Isofucosterol & $1,9 \%$ \\
\hline
\end{tabular}

In an attempt to throw light on the possibility of utilization of the meal of grape seeds as a potential source of protein, the defatted seed meal was evaluated for its protein content and amino acid composition. It was found that the protein content of the defatted meal amounts to $24,6 \%$ which is lower than those found in cottonseed and soybean meals (1). Table VI illustrates amino acid, composition of grape seed meal which contains large proportions of essential amino acids, but they are generally lower in their quantities than those in the other oil seed meals. Therefore, it is recommended that grape seed meal can be used in a mixture with other vegetable proteins to give better amino acid balance for different feeding purposes.

Table VI

Amino Acid Constituents of Grape Seed Meal

\begin{tabular}{|c|c|}
\hline $\begin{array}{l}\text { Amino Acid } \\
\text { constituents }\end{array}$ & $\begin{array}{l}\text { Amino Acid } \\
\mathrm{g} / 16 \mathrm{~g} \mathrm{~N}\end{array}$ \\
\hline Lysine & 3,57 \\
\hline Histidine & 1,72 \\
\hline Arginine & 4,0 \\
\hline Threonine & 1,45 \\
\hline Valine & 3,46 \\
\hline Methionine & 0,9 \\
\hline Cystine & 0,0 \\
\hline Isoleucine & 1,97 \\
\hline Leucine & - \\
\hline Tyrosine & 2,15 \\
\hline Phenylalanine & 2,60 \\
\hline
\end{tabular}

It is generally concluded that grape seeds can be used as potential source of oil and protein. The absence of linolenic acid in the oil and the presence of high levels of tocotrienols with considerable amounts of tocopherols can improve the oil stability. Owing to the fact that grape seeds, locally produced as by-product, have not been previously studied in details, the present investigations will assist to increase its economic utilization for different purposes. 


\section{ACKNOWLEDGMENT}

Appreciation is expressed to the Egyptian Vineyards and Distilleries Company (Ginaclis) Alexandria, for supplying the pomaces.

\section{REFERENCES}

1. Eckey, E.W.- "Vegetable Fats and Oils".- Reinhold Publishing Corporation, N.Y. (1954).

2. Frank Rabak.- "Grape Seed Oil".- J. Ind. Eng. Chem. 13 (1921) 919-921.

3. Emile A and Henri, C.- "Study of some French and Algerian Grape Seeds Oils".- Ann. Office Nat. Comb. liquides 2 (1927) 585-99; Bull. Soc. encour. ind. nat. 126 (1927) 542-559

4. Otin, C. and Dima, M.- "Chemico Technical Investigation of the Oil obtained from Grape Seeds from Various Wine Growing Districts in Roumania".- Allgem. oel-u. Fett. Zig. 30 (1933) 71-7, 135-144.

5. Kaufmann, H.P. and Fiedler, H.- "The Field of Fats XXXVI. Possibilities of Developing New German Oil Supply Sources. I. Grape Seed Oil".- Fette Seifen 44 (1937) 286-289.

6. Kaufmann, H.P. and Sprick, M.- "German Grape Seed Oils from the 1937 Harvest". - Ibid 45 (1938) 288-289.

7. Kaufmann, H.P. and Fiedler, H. LXXII.- "Extraction of Grape Seed Oil".- Forschungsdienst 8 (1939) 346-365; Chem. Zentr. I (1940) 1592-1594.

8. Menesson, J. and Maricourt, A.- "The Production of Oil of Raisin Seeds".- Inds. Agr. et Aliment. 70 (1953) 769-778.

9. Morand, P. and Silvestre, J.- "A vegetable Oil Containing Polyunsaturated Fatty Acids: Grape Seed Oil. Analytical Characteristics, Alimentary and Dietetic Qualities".- Ann. Fats. et Expert. Chim. 53 (1960) 193-203. Morano. P.- "Raisin Seed Oil and Cholesterol".- Trav. Soc. Pharm. Montpellier 19 (1959) 51-56.

10. Flanzy, J. and Flanzy, M.- "Evaluation of Raisins Seed Oil as to Valuable Fatty Acids".- Ann. Inst. Natl. Recherche Agron. Ser. E8 (1959) 107-111.

11. Ekster, Ya. E. and Osipchuk, V.- "Chemical Composition of Grape Seeds".- Vanodelie i Vinogradrastvo SSSR 13 (1964) 67-75.

12. Flanzy, M. and Dubois, P.- "The Determination of Total Tocopherols. Application to Grape Seeds Oil".- Ann. Technol. Agr. 13 (1964) 67-75.

13. Dubois, P.- "Autoxidation of Grape Seed Oil. I. Effect of Tocopherols".- Ann. Technol. Agr. 13 (1964) 97-103.

14. Miric, M.; Lalic, Z. and Miletic, I.- "Composition of Grape Seeds".Hrana Ishrana 18 (1977) 227-232.

15. Testa, G. and Guttardi, P.- "By-Products of Wine Making: Grape Seeds".- Vignevini 4 (1977) 39-42.

16. Khadzhiiski, Ts.- "Composition of Grape Seeds and Oil Produced from them".- Maslo-Sapunena Prom-St. 15 (1979) 1-8.

17. Gallander James, F. and Peng Andrew, C.- "Lipid and Fatty Acid Compositions of Different Grape Types".- Am. J. Enol. Vitic 31 (1980) 24-27.

18. Yoon, H.; Kwon, J.; Choi, J.; Hwany, J. and Shin, D.- "Studies on the Development of Food Resources from Waste Seeds. I. Chemical Composition of Grape seeds".- Hanguk Sikpum Kwahakhoe Chi 14 (1982) 250-256.
19. Fazio, G.; Gattuso, A.M.; Cillufo, V. and Arcaleo, G.- "Preparation and characterization of Protein Materials from Grape Seeds Meals".Riv. Soc. Ital. Sci. Aliment. 12 (1983) 469-478.

20. Yoo, J. Shin, D. and Min, B.- "Composition of Grape Seed Oil".Hon'guk Sikpum Kwahakhoechi 16 (1984) 257-260.

21. Kamel, B.S.: Dawson, H. and Kakuda, Y.- "Characteristics and Composition of Melon and Grape Seed Oils and Cakes".- J. Am. Oil Chemists'Soc. 62 (1985) 881-883.

22. Tarandzhiiska, R.; Lichev, V.; Chorbanov, D.; Chorbanov, B. and Dimov, V.- "Triglycerides and Fatty acid Composition of Grape Seed Oil".- F.E.C.S. Int. Conf. Chem. Biotechnol. Biol. Act. Nat. Prod. (Proc. J., 3rd (1985) (Pub. 1987), 4, 486-490, VCH: Weinheim, Fed. Rep. Ger.

23. El-Zeany, B.A.; Abdel-Kawy, M. and Amer, M.M.- "Egyptian Grape Seed Oil. part I. Extraction, Constants, Fatty Acids and Unsaponifiables".- Grasas y Aceites 33 (1982) 158-161.

24. El-Zeany, B.A.; Abdel Kawy, M. and Amer. M.M.- "Egyptian Grape Seed Oil. Part 2. Triglyceride Structure".- Ibid 33 (1982) 212-215.

25. Hassan, M.M.; Souka, L.M. and Gad, A.M.- "Fatty Acid Composition of Corchorus, Olitorius and Vities Vinefera Seed Oils".- Seifen Öle Fette Wachse 97 (1971) 959-961.

26. American Oil Chemists'Soc.- "Official and Tentative Methods".- 2nd Edition, Chicago, 1957.

27. Clark, E.P.- "Semimicro Quantitative Organic Analysis".- Academic Press, New York (1943).

28. Moore, S.; Spackmand, D.H. and Stein, W.H.- "Chromatography of Amino Acids on Sulphonated Polystyrene Resins".- Anal. Chem. 30 (1958) 1185-1190.

29. Spackman, D.H. Stein, W.H. and Moore, S.- "Automatic Recording Apparatus for Use in the Chromatography of Amino Acids".- Anal. Chem. 30 (1958) 1190-1205.

30. El-Nockrashy, A.S.; El-Shattory, Y. and Gad, A.M.- "Physical and Chemical Characteristics of Crude and Refined Hydraulic and Solvent Extracted Cottonseed Oil".- Grasas y Aceites 20 (1969) 286-289.

31. Pons, W.A. Jr; Kuck, J.C. and Phrampton, V.L.- "Colour Index for Cottonseed Oils".- J. Am. Oil Chemists'Soc. 37 (1960) 671-673.

32. Hassanein MM - "Changes in the Content and Compositions of Lipids During Maturation of Soybean and Sunflower Seeds".- M. Sc. Thesis, Ain Shams University, Faculty of Science, Botany Department.

33. Slover, H.T.; Thompson, R.H. Jr. and Merola, G.V.- "Determination of Tocopherols and Sterols by Capillary Gas Chromatography".- J. Am. Oil Chemists'Soc. 60 (1963) 1524-1528.

34. El-Shami, S.- "Glyceride Structure and Sterol Composition of SOS-7 Halophyte Oil".- Grasas y Aceites 42 (1991) 211-215.

35. Usuki, R.; Endo, Y.; Suzuki, T. and Kaneda, T.- "Prooxidant Activity of Chlorophylls and their Related Compounds on Autoxidation of Edible Oils.- "16th. World Congress of ISF, Budapest, October (1983), Paper Abstacts, pp. 54

36. Usuki, R.; Suzuki, T.; Endo, Y. and Kaneda, T.- "The Role of Carotenoids in the Oxidative Stability of Edible Oils in the Presence of Tocopherols and Chlorophylls".- Proceedings 19th. ISF World Congress, 1 (1988) 542-548, Tokyo.

(Recibido: Noviembre 1991) 